\title{
Efek pemberian ekstrak kedelai hitam (Glycine soja) terhadap histologi femur pada mencit (Mus musculus) ovariektomi
}

\author{
Effects of black soya extract (Glycine soja) on histology femur of mice \\ (Mus musculus) ovariectomized \\ Mahriani*, Resa Miftahatu Yuniar, Masrurotul Hasanah dan Eva Tyas Utami \\ Jurusan Biologi, Fakultas Matematika dan Ilmu Pengetahuan Alam,Universitas Jember \\ *Email:yani_hendro@yahoo.com
}

Diterima 29 Desember 2020

Disetujui 8 Maret 2021

\section{INTISARI}

Tulang merupakan struktur yang dinamik dan mengalami remodeling atau proses regenerasi secara terusmenerus. Remodeling tulang meliputi proses formasi oleh osteoblas dan resorpsi oleh osteoklas.Keseimbangan antara formasi dan resorpsi dipengaruhi oleh hormon estrogen. Defisiensi estrogen dapat menyebabkan meningkatnya resorpsi tulang.Ovariektomi merupakan model untuk defesiensi estrogen dengan melakukan pengangkatan ovarium. Salah satu cara untuk mengatasi defesiensi estrogen dapat dilakukan dengan pemberian fitoestrogen. Tujuan dari penelitian ini adalah untuk mengetahui efek pemberian ekstrak kedelai hitam (Glycine soja) terhadap histologi femur mencit (Mus musculus) ovariektomi. Pada penelitian ini digunakan dosis ekstrak kedelai hitam 0,42 g/ml/hari dan 0,63 $\mathrm{g} / \mathrm{ml} / \mathrm{hari}$, yang diberikan secara oral selama 30 hari. Penelitian dilaksanakan dengan Rancangan Acak Lengkap, 4 perlakuan dan 6 ulangan.Pengamatan dilakukan terhadap jumlah sel osteoblas dan jumlah sel osteoklas pada preparat histologi femur.Hasil penelitian menunjukkan bahwa pemberian ekstrak kedelai hitam dengan dosis $0.42 \mathrm{~g} / \mathrm{ml} /$ hari selama 30 hari,secara nyata dapat meningkatkan jumlah osteoblas dan menurunkan jumlah osteoklas pada femur mencit ovariektomi.

Kata kunci: kedelai hitam, osteoblas, osteoklas, ovariektomi

\begin{abstract}
Bone is a dynamic structure and has the process to remodelling or regeneration. Bone remodelling includes the process of formation by osteoblasts and the process of resorption by osteoclasts. The balancing between formation and resorption are assisted by the estrogen hormone.Estrogen deficiency can lead the bone resorption. Ovariectomy is a model for estrogen deficiency by removing the ovaries. One way to overcome estrogen deficiency can be solved by offering phytoestrogens. This research have purpose to determine the effect of black soybean extract (Glycine soja) on the histology of the femur mice (Mus musculus) ovariectomized. In this research used a dose of black soybean extract as many as $0.42 \mathrm{~g} / \mathrm{ml} /$ day and 0.63 $\mathrm{g} / \mathrm{ml} /$ day, which are given orally for 30 days. The research is conducted with a completele randomized design with 4 treatments and 6 replications. Observations are made on the number of osteoblasts and the number of osteoclasts on the histological of the femur. The results showed that offering black soybean extract at a dose of $0.42 \mathrm{~g} / \mathrm{ml} /$ day for 30 days have significantly increased the number of osteoblasts and have decreased the number of osteoclasts in the femur of ovariectomized mice.
\end{abstract}

Keywords: black soybean, osteoblasts, osteoclast, ovariectomy 


\section{PENDAHULUAN}

Tulang tersusun atas matriks tulang dan sel-sel tulang yaitu osteoklas, osteoblas dan osteosit. Tulang merupakan struktur yang dinamik dan mengalami proses regenerasi secara terusmenerus yang disebut remodeling tulang. Proses remodeling tulang meliputi proses pembentukan (formasi) oleh osteoblas dan resorpsi oleh osteoklas (Tortora \& Derrickson, 2014).Keseimbangan antara formasi tulang dan resorpsi tulang dipengaruhi oleh hormon, antara lain hormon estrogen dan paratiroid (Seibel, 2005; Kini \& Nandeesh, 2012).

Estrogen merupakan hormon steroid yang dihasilkan oleh ovarium dan berperan untuk meningkatkan aktivitas osteoblas dan menurunkan aktivitas osteoklas pada proses remodeling tulang (Tortora \& Derrickson, 2014).Estrogen juga berperan dalam menjaga homeostatis kadar kalsium melalui aktifitas osteoblas dan osteoklas dalam tulang (Sabri, 2011).Estrogen berperan memodulasi proliferasi dan diferensiasi osteoblas, serta meningkatkan sekresi sitokin yang menghambat aktivitas osteoklas (Bilbao et al., 2011).

Ovariektomi merupakan tindakan pengangkatan ovarium pada sistem reproduksi betina dan merupakan model untuk defisiensi estrogen (Alagwu \& Nneli, 2005).Defisiensi estrogen dapat menyebabkan meningkatnya resorpsi tulang(Khosla et al., 2012).Kurangnya estrogen dapat menjadi inhibitor interaksi estrogen dengan ER $\beta$ pada osteoblas, sehingga dapat menghambat progenitor osteoblas dalam sekresi Osteoprotegerin (OPG) yang merupakan faktor penghambat osteoklastogenesis (Bell, 2003).Kondisi defisiensi estrogen dapat diatasi dengan pemberian fitoestrogen (Wiyasa et al., 2008).

Fitoestrogen mengandung senyawa yang mirip dengan estrogen endogen sehingga dapat memberikan efek estrogenik. Senyawa fitoestrogen dapat berupa isoflavon dan lignan, yang ditemukan pada biji- bijian terutama kacang-kacangan, buah-buahan, dan sayuran
(Chen et al., 2015). Kedelai hitam merupakan salah satu sumber fitoestrogen yang mengandung isoflavon (Nurrahman, 2015). Oleh karena itu dilakukan penelitian untuk mengetahui pengaruh pemberian ekstrak kedelai hitam terhadap histologi tulang pada mencit ovariektomi.

\section{MATERI DAN METODE}

\section{Materi}

Bahan yang digunakan sebagai hewan uji dalam penelitian ini adalah mencit (Mus musculus) betina strain Balb/C umur 60 hari yang diperoleh dari PUSVETMA, kedelai hitam, pakan pellet, aquades, ketamin 10\%, xylazine, benang silk (One med), benang catgut (One med), serbuk gergaji kayu, Povidone iodine, alkohol 70\%, antibiotik,Sodium Chloride 0,9\%,kasa steril, gloves, masker, kertas saring, gelas objek, gelas penutup, chloroform, larutan fiksatif PBS formalin.

\section{Metode}

\section{Persiapan Hewan Uji}

Hewan uji mencit (Mus musculus) strain Balb/C umur 60 hari, ditempatkan dalam kandang berukuran $34 \mathrm{~cm}$ x $25 \mathrm{~cm}$ x $12 \mathrm{~cm}$ dengan alas serbuk gergaji kayu steril dengan tutup kawat.Mencit diberi pakan standar berupa pelet dan diberikan minum secara ad libitum.

\section{Preparasi Ovariektomi Unilateral Mencit}

Ovariektomi unilateral atau pengambilan salah satu ovarium dilakukan melalui pembedahan. Mencit dibius secara intramuskular dengan ketamin $10 \%$ dan xylazine dengan perbandingan 1:1 sebanyak $0,05 \mathrm{ml}$. Mencit dibedah pada bagian abdomen kemudian dilakukan penyayatan dengan menggunakan gunting pada kulit bagian luar dengan lebar $1,5 \mathrm{~cm}$ dan kulit bagian dalam $1 \mathrm{~cm}$. Selanjutnya diambil salah satu ovarium kemudian dijepit dengan klem arteri dan diikat bagian ujung oviduk dengan benang silk. Selanjutnya salah satu ovarium dipotong dengan gunting. Kemudian direposisi kembali organ dalam yang telah dikeluarkan ke dalam abdomen 
dan diberi 0,5 ml larutan Sodium Chloride 0,9\% (Ulfa, 2017).

Proses penutupan dengan cara dijahit menggunakancut gut chromic ukuran 3.0 pada bagian muskulus obliquus abdominis internus, sedangkan pada muskulus obliquus abdominis eksternus menggunakan benang silk ukuran 3.0. Selanjutnya diberi povidone iodine pada bagian yang luka diinjeksi dengan antibiotik sebanyak 0,05 ml. Kemudian diberi paracetamol 1 sendok teh/200 ml aquades secara ad libitum selama 1 minggu (Ulfa, 2017).

\section{Pembuatan Ekstrak Tepung Kedelai Hitam}

Kedelai hitam ditumbuk kasar kemudian dioven pada suhu $40-45^{\circ} \mathrm{C}$ selama $2-3$ hari, selanjutnya digiling dengan menggunakan grinder hingga menjadi tepung. Kemudian tepung kedelai hitam diayak dengan ayakan berukuran 60 mesh.Selanjutnya diberi pelarut alkohol $70 \%$ dengan perbandingan 1:4 dan dihomogenkan, kemudian dimaserasi selama 2 x 24 jam untuk memisahkan supernatan dan pelet. Supernatan disaring menggunakankertas saring.Filtrat yang diperoleh dimasukkan ke dalam rotary evaporator dengan suhu $90^{\circ} \mathrm{C}$ hingga diperoleh filtrat bebas alkohol. Selanjutnaya filtrat dipanaskan di waterbath selama \pm 8 jam untuk mendapatkan crude extract dalam bentuk pasta (Ulfa, 2017).

\section{Perlakuan Hewan Uji}

Perlakuan yang dilakukan dalam penelitian ini adalah pemberian ekstrak tepung kedelai hitam yang diberikan secara oral menggunakan jarum sonde. Pemberian ekstrak tepung kedelai hitam dimulai pada hari ke-91 pasca ovariektomi, diberikan secara gavage selama 30 hari dengan cara mencampurkan takaran pasta pada $1 \mathrm{ml}$ akuades sesuai dengan perlakuan yaitu 0,42 $\mathrm{g} / \mathrm{ml} /$ hari dan $0,63 \mathrm{~g} / \mathrm{ml} /$ hari. Pembedahan untuk pengambilan tulang femur dilakukan 1 hari setelah selesai pemberian ekstrak kedelai hitam kemudian dilanjutkan dengan pembuatan preparat histologi.

\section{Pembuatan Preparat Histologi Femur}

Pada akhir perlakuan masing-masing mencit dieuthanasia menggunakan cairan kloroform dengan cara perinhalasi, kemudian dilakukan pembedahan, diambil femurnya dan dibuat preparat histologi. Pembuatan preparat tulang diawali dengan dekalsifikasi untuk menghilangkan $\mathrm{Ca}^{2+}$ yang ada di dalam jaringan tulang, sehingga jaringan menjadi lunak dan dapat diproses untuk pembuatan preparat dengan metode parafin (Sumaryati, 2012).Metode parafin dilakukan dengan cara fiksasi, dehidrasi, clearing, infiltrasi, embedding, section, affixing dan mounting (Suntoro, 1983).

\section{Parameter Pengamatan pada Penelitian}

Parameter pengamatan dilakukan dengan menghitung jumlah osteoblas dan osteoklas pada preparat histologi femur pada masing-masing perlakuan. Perhitungan dilakukan secara manual di daerah metafisis tulang yang merupakan penanda aktivitas sel dalam proses remodeling tulang. Pengamatan menggunakan mikroskop binokuler (Olympus) perbesaran 400x dan aplikasi optilab. Ciri-ciri osteoblas berbentuk kubus dan berinti tunggal, sedangkan osteoklas berukuran besar, bentuknya tidak beraturan, dan berinti banyak (Mescher, 2012).

\section{Analisis Data}

Hasil pengamatan jumlah osteoblas dan osteoklas dianalisis menggunakan uji Anova dengan taraf kepercayaan $95 \%$ atau $\alpha=0,05$, selanjutnya untuk mengetahui perbedaan pengaruh perlakuan pemberian ekstrak tepung kedelai hitam pada mencit ovariektomi dilakukan uji DMRT (Duncan Multiple Range Test) (Steel \& Torrie, 1993).

\section{HASIL}

\section{Pengaruh Pemberian Ekstrak Kedelai Hitam Terhadap Jumlah Osteoblas}

Hasil penghitungan rata-rata jumlah osteoblas, dan hasil analisis One Way Anova diperoleh nilai signifikasi $\mathrm{p}=0,00<0,05$. Hal ini menunjukkan 
bahwa perlakuan pemberian ekstrak kedelai hitam berpengaruh nyata terhadap rata-rata jumlah osteoblas. Hasil penghitungan rata-rata jumlah osteoblas dapat dilihat pada Tabel 1.

Tabel 1. Rata-rata jumlah osteoblas pada tulang femur mencit ovariektomi pasca pemberian ekstrak kedelai hitam

\begin{tabular}{cc}
\hline Perlakuan & $\begin{array}{c}\text { Rata-rata Jumlah Osteoblas } \\
(\overline{\boldsymbol{x}} \pm \text { SD })\end{array}$ \\
\hline K- & $(44,00 \pm 4,899)^{\mathrm{b}}$ \\
K+ & $(29,83 \pm 2,317)^{\mathrm{a}}$ \\
D1 & $(51,17 \pm 3,189)^{\mathrm{c}}$ \\
D2 & $(47,50 \pm 3,082)^{\mathrm{bc}}$ \\
\hline
\end{tabular}

Angka pada kolom yang sama, yang diikuti huruf sama menunjukkan tidak berbeda nyata menurut uji Duncan (DMRT) $\alpha=5 \%$. K-: Kontrol negative; K+: Kontrol positif: D1: Dosis 0,42 g/ml/hari, D2: Dosis 0,63 g/ml/hari

\section{Pengaruh Pemberian Ekstrak Kedelai Hitam Terhadap Jumlah Osteoklas}

Hasil penghitungan rata-rata jumlah osteoklas, dan hasil analisis One Way Anova diperoleh nilai signifikasi $\mathrm{p}=0,00<0,05$. Hal ini menunjukkan bahwa perlakuan pemberian ekstrak kedelai hitam berpengaruh nyata terhadap rata-rata jumlah osteoklas. Hasil penghitungan rata-rata jumlah osteoklas dapat dilihat pada Tabel 2.

Tabel 2. Rata-rata jumlah osteoklas pada tulang femur mencit ovariektomi pasca pemberian ekstrak kedelai hitam

\begin{tabular}{cc}
\hline Perlakuan & $\begin{array}{c}\text { Rata-rata Jumlah Osteoklas } \\
(\overline{\boldsymbol{x}} \pm \mathrm{SD})\end{array}$ \\
\hline $\mathrm{K}-$ & $(29,33 \pm 2,160)^{\mathrm{a}}$ \\
$\mathrm{K}+$ & $(32,17 \pm 3,312)^{\mathrm{a}}$ \\
$\mathrm{D} 1$ & $(17,17 \pm 3,764)^{\mathrm{b}}$ \\
D2 & $(19,50 \pm 4,231)^{\mathrm{b}}$ \\
\hline
\end{tabular}

Angka pada kolom yang sama, yang diikuti huruf sama menunjukkan tidak berbeda nyata menurut uji Duncan (DMRT) $\alpha=5 \%$. K-: Kontrol negative; K+: Kontrol positif: D1: Dosis 0,42 g/ml/hari, D2: Dosis 0,63 g/ml/hari.

\section{Histologi tulang femur mencit}

Gambaran osteoblas dan osteoklas pada histologi tulang femur mencit ovariektomi pasca pemberian ekstrak kedelai hitam seperti terlihat pada Gambar 1.

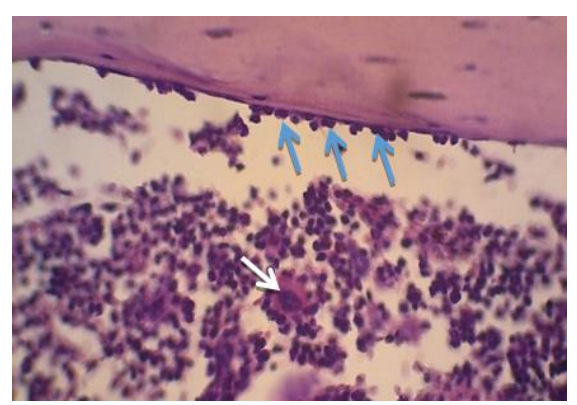

(a)

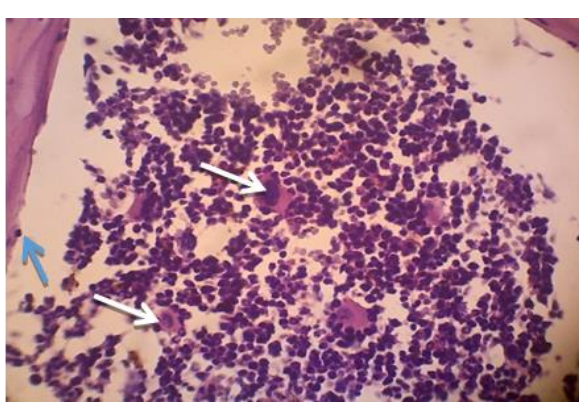

(b)



(c)

Gambar 1. Histologi tulang femur mencit ovariektomi pasca pemberian ekstrak kedelai hitam (a) Kontrol Negatif; (b) Kontrol Positif: dan (c) D1, Dosis 0,42 g/ml/hari.

Keterangan: Osteoblas: Panah biru; Osteoklas: panah putih

\section{PEMBAHASAN}

\section{Pengaruh Pemberian Ekstrak Tepung Kedelai Hitam Terhadap Jumlah Osteoblas}

Rata-rata jumlah osteoblas kelompok kontrol positif mengalami penurunan jika dibandingkan dengan kelompok kontrol negatif. Hal ini diduga disebabkan oleh kondisi defisiensi estrogen akibat ovariektomi unilateral. Disebutkan bahwa hormon estrogen berperan penting dalam peningkatkan aktivitas osteoblas (Tortora \& Derrickson, 2014). Osteoblas merangsang pembentukan tulang (Yamaguchi, 2002). Oleh karena itu penurunan kadar hormon estrogen dalam tubuh akibat ovariektomi juga akan mengakibatkan penurunan jumlah osteoblas.

Rata-rata jumlah osteoblas kelompok dosis $0,42 \mathrm{~g} / \mathrm{ml} / \mathrm{hari}$ mengalami peningkatan dibandingkan dengan kontrol positif. Hal ini diduga karena pemberian ekstrak tepung kedelai 
hitam dengan dosis $0,42 \mathrm{~g} / \mathrm{ml} /$ hariselama 30 haridapat meningkatkan estrogen dalam tubuh sehingga dapat berperan meningkatkan jumlah osteoblas. Disebutkan bahwa peningkatan jumlah osteoblas dapat terjadi karena adanya pemberian fitoestrogen mampu berikatan dengan reseptor estrogen pada berbagai jaringan tubuh termasuk tulang (Kuiper et al.,1998; Mann et al., 2007).

Fitoestrogen dapat berupa isoflavon yang mempunyai struktur kimia mirip dengan estradiol sehingga senyawa ini dapat memberikan efek estrogenik (Chen et al., 2015). Isoflavon dapat berikatan dengan reseptor estrogen $\mathrm{ER}_{\beta}$ pada osteoblas sehingga dapat menstimulasi proliferasi osteoblas (Yamaguchi et al., 2002). Disebutkan oleh Suarsana et al. (2014) bahwa pemberian tepung tempe $4 \mathrm{mg} / 200 \mathrm{gBB} / \mathrm{hari}$ dapat meningkatkan jumlah osteoblas.

Kelompok perlakuanperlakuan pemberian ekstrak kedelai hitam dosis $0,42 \mathrm{~g} / \mathrm{ml} / \mathrm{hari}$ tidak berbeda nyata dengan dosis $0,63 \mathrm{~g} / \mathrm{ml} / \mathrm{hari}$, namun pada pada perlakuan dosis $0,63 \mathrm{~g} / \mathrm{ml} / \mathrm{hari}$ cenderung mempunyai rata-rata jumlah osteoblas yang lebih rendah. Hal tersebut diduga disebabkan peningkatan pemberian fitoestrogen dengan dosis $0,63 \mathrm{~g} / \mathrm{ml} /$ hariselama 30 hari, kurang efektif untuk meningkatkan jumlah osteoblas, karena pada dosis yang tinggi maka kandungan isoflavon genestein juga tinggi. Disebutkan bahwa pemberian fitoestrogen genestein yang tinggi dapat mengakibatkan meningkatnya produksi Nitrit oksida (NO) (Brune et al., 1999; Wang et al., 2005). Dilaporkan bahwa pemberian kacang tunggak sebagai sumber fitoestrogen pada tikus ovariektomi, pada dosis yang tinggi menyebabkan penurunan jumlah osteoblas, yang diduga karena meningkatkan produksi nitrit oksida yang bersifat sebagai radikal bebas sehingga dapat menyebabkan kematian sel osteoblas (Darmadi et al., 2011).

\section{Pengaruh Pemberian Ekstrak Tepung Kedelai Hitam Terhadap Jumlah Osteoklas}

Rata-rata jumlah osteoklas pada kontrol positif cenderung mengalami peningkatan dibandingkan dengan kelompok kontrol negatif. Hal tersebut diduga karena ovariektomi menyebabkan defisiensi estrogen dan mengakibatkan pembentukan osteoklas meningkat. Disebutkan bahwa ovariektomi menyebabkan defisiensi estrogen dan kondisi defisiensi estrogen menyebabkan aktivitas osteoklas meningkat (Masyitha, 2006; Nebel et al., 2009).Disebutkan bahwa kurangnya estrogen dapat menjadi inhibitor interaksi estrogen dengan $\mathrm{ER} \beta$ pada osteoblas, sehingga dapat menghambat progenitor osteoblas dalam sekresi Osteoprotegerin (OPG) yang merupakan faktor penghambat osteoklastogenesis (Bell, 2003). Hasil penelitian Suarsana et al. (2014) menyebutkan bahwa kelompok tikus ovariektomi bilateral menunjukkan jumlah osteoklas yang lebih banyak dibandingkan dengan kelompok tikus kontrol.

Rata-rata jumlah osteoklas pada kelompok perlakuan dosis $0,42 \mathrm{~g} / \mathrm{ml} / \mathrm{hari}$ tidak berbeda nyata dibanding kelompok perlakuan dosis 0,63 $\mathrm{g} / \mathrm{ml} /$ hari, namun kelompok dosis $0,42 \mathrm{~g} / \mathrm{ml} /$ hari cenderung mempunyai jumlah rata osteoklas yang lebih rendah. Hal tersebut diduga karena pemberian esktrak tepung kedelai hitam dapat menurunkan jumlah osteoklas.Disebutkan bahwa estrogen dapat menghambat pembentukan osteoklas melalui reseptor estrogen yang terdapat pada osteoklas sehingga mencegah terjadinya diferensiasi sel prekursor osteoklas (Bell, 2003; Nebel et al., 2009).Lebih lanjut disebutkan bahwa tikus ovariektomi yang diberi tepung tempepada dosis $4 \mathrm{mg} / 200 \mathrm{gBB} /$ hari menunjukkan jumlah osteoklas yang lebih rendah dibandingkan dengan jumlah osteoklas pada tikus ovariektomi yang tidak diberi tepung tempe (Suarsana et al., 2014).

\section{SIMPULAN}

Berdasarkan penelitian ini dapat disimpulkan bahwa pemberian ekstrak kedelai hitam dengan dosis $0,42 \mathrm{~g} / \mathrm{ml} /$ hari selama 30 hari secara nyata dapat meningkatkan jumlah osteoblas dan menurunkan jumlah osteoklas pada femur mencit ovariektomi. 


\section{UCAPAN TERIMA KASIH}

Terimakasih disampaikan kepada Universitas Jember atas biaya Hibah Reworking dengan sumber dana internal DIPA Universitas Jember 2020.

\section{DAFTAR PUSTAKA}

Alagwu EA, Nneli RO. 2005. Effect of Ovariectomy on The Levels of Plasma Sex Hormones In Albino Rats. Nigerian Journal of Physiological Sciences 20(1-2): 90-94.

Bell NH. 2003. RANK Ligand and The Regulation of Skeletal Remodeling. J Clin Invest. 111(8): 1120-1122.

Bilbao NJL, Sanchez CA, Gil-Antunano SP. 2011. Bone Metabolism Regulation Through RANK-RANKL-OPG System. Rev Osteoporos Metab Miner 3(2): 105-112

Brune B, Knethen AV, Sandau KB. 1999. Nitric oxide (NO): an effector of apoptosis. Cell Death and Differentation 6: 969-975.

Chen MN, Lin C-C, Liu C. 2015. Efficacy of phytoestrogens for menopausal symptoms: a meta-analysis and systemic review. Climateric 18(2):1-20.

Darmadi D, Nurdiana, Norahmawati E. 2011. Efek Ekstrak Kacang Tunggak Terhadap Osteoblas dan Osteoklas pada Tikus dengan Ovariektomi. Jurnal Kedokteran Brawijaya 26(3): 15:1-155.

Khosla S, Oursler MJ, Monroe DG. 2012. Estrogen and the skeleton. Trends in Endocrinology and Metabolism 23(11): 576581.

Kini U, Nandeesh BN. 2012. Physiology of Bone Formation, Remodeling, and Metabolism. Springer-Verley: Berlin.

Kuiper GGJM, Lemmen JG, Carlsson BO, Corton JC, Safe SH, Saag PTDV, Burg BVD, Gustafsson J. 1998. Interaction of Estrogenic eceptor B. Endocrinology 139(10): 42524263

Mann GE, Rowlands DJ, Li FYL, Winter P, Siow RCM. 2007. Activation of endothelial nitric oxide synthase by dietary isoflavones: Role of NO in Nrf2-mediated antioxidant gene expression. Cardiovascular Research 75: 261-274.
Masyitha D. 2006. Struktur Mikroskopik tulang Mandibula Pada Tikus Ovariektomi dan Pemberian Pekan Rasio Fosfat/kalsium Tinggi. Media Kedokteran Hewan 22(2): 112-117.

Mescher AL. 2012. Histologi Dasar Junqueira Teks \&Atlas. EGC: Jakarta.

Nebel D, Bratthall G, Warfvinge G, Nilsson BO. 2009. Effect of Ovariectomy and Aging on Tooth Attachment in Female Mice Assessed by Morphometric Anaysis. Acta Odontologica Scandinavica. 67: 8-12.

Nurrahman. 2015. Evaluasi komposisi zat gizi dan senyawa antioksidan kedelai hitam dan kedelai kuning. Jurnal Aplikasi Teknologi Pangan 4(3): 89-93.

Sabri M. 2011. Aktivitas Ekstrak Etanol Batang Sipatah-patah (Cissus quadrangula Salibs) sebagai Antiosteoporosis pada Tikus (Rattus norvegicus). Disertasi. Sekolah Pasca Sarjana Institut Pertanian Bogor.

Seibel M. 2005. Biochemical Markers of Bone turnover part 1: Biochemistry and variability. Clin Biochem Rev. 26: 97-122.

Steel R, Torrie J. 1993. Principles and Procedures of Statistics. Gramedia Pustaka: Jakarta.

Suarsana IN, Silitonga SL, Dharmawan INS, Kardenadan IM, Priosuryanto BP. 2014. Pemberian Tepung Tempe Meningkatkan Kualitas Tulang Pada Tikus Ovariektomi.Jurnal Veteriner 15(4): 548556.

Sumaryati. 2012. Dekalsifikasi Metode Von Ebner's.Prosedur Kerja Baku/Standart Operating Procedure (SOP). No: P-O14. Yogyakarta: Laboratorium Histologi dan Biologi Sel Fakultas Kedokteran, Universitas Gadjah Mada.

Suntoro SH. 1983. Metode Pewarnaan. Bantara Karya Aksara: Jakarta.

Tortora G, Derrickson B .2014. Principles of Anatomy and Physiology. John Wiley \& Sons, Inc.: Hoboken.

Ulfa YM. 2017. Efek Ekstrak Tepung Kedelai Hitam (Glycine soja) terhadap Struktur Histologi Uterus Mencit (Mus musculus) Strain Swiss Webster Ovariektomi Unilateral. Skripsi. Universitas Jember.

Wang X, Chen S, Ma G, Ye M, Lu G. 2005. Genestein protects dopaminegic neuron by 
inhibiting microgial avtivation. Neuroreport 16(3): 267-270

Wiyasa IWA, Norahmawati E, Soehartono. 2008. Pengaruh isoflavone genistein dan daidzein ekstrak tokbi (Peuraria lobata) strain Kangean terhadap jumlah osteoblas dan osteoklas (Rattus novergicus) Wistar hipoestrogenik. Indonesian Journal of Obstetrics and gynecology 32(3): 148-152.

Yamaguchi M. 2002. Isoflavone and Bone metabolism:its cellular mechanism and preventive role in bone loss. Journal of Health science 48(3): 209-222. 